\title{
Mitos Militerisme pada Busana Kampanye \\ (Analisis Semiotika Roland Barthes Busana Kampanye \\ Agus Harimurti Yudhoyono-Sylviana Murni)
}

Dudi Hartono, Riyan Hidayatullah

Universitas Mercu Buana, Jakarta, bungdudi@mercubuana.ac.id,* riyanhidayat38@yahoo.com

\section{Myth of Militarism in the Election Campaign Fashion (Roland Barthes' Semiotic Analysis on the Campaign Uniform of Agus Harimurti Yudhoyono-Sylviana Murni)}

\begin{abstract}
The importance of fashion campaigns in the process of political communication in Indonesia has gained its own spotlight over the years. Clothing is seen to have an artifactual communication function as a political statement, or at least the image the user wants to display. So the meaning of dressing the contestants was faced with a variety of public interpretations. Clothing has an ambiguous double face. On one side, the face of the dress looks attractive and seductive. Conversely, on the other hand, clothing also have the meaning of falsehood as well as deceive. AHY -SYLVI campaign fashion is modeled, or at least inspired, from military tactical uniforms, $A H Y$ institution originated before deciding to participate in Jakarta 2017 Regional Head Election. Agus Harimurti Yudhoyono calls his campaign uniform with TactiCool term. It is a very entertaining and slang term by blending the actual term Tactical and Cool. Moreover, then the design of uniform was made body-fit that makes the clothes look more fashionable. By choosing a black color and sticking emblems here and there make the clothes seems very army-look. To examine the AHY-SYLVI campaign uniform and the various embedded symbols, the authors use the Roland Barthes Semiotics analysis approach. Barthes's perspective becomes one of its semiological traits that opens up the new realm of semiology, that is, further excavations of marking to achieve the myths that work in the daily reality of society. This is what the authors of Roland Barthes's semiotics theory say is more appropriate in the choice of AHY-SYLVI fashion or uniform campaign as a particular symbol.
\end{abstract}

Keywords: Myth of militarism, Semiotics; campaign fashion; Roland Barthes

\begin{abstract}
ABSTRAK
Pentingnya peran busana kampanye dalam proses komunikasi politik di Indonesia telah mendapatkan sorotan tersendiri selama ini. Pakaian dipandang memiliki fungsi komunikasi artifaktual sebagai pernyataan politik, atau setidak-tidaknya citra yang ingin ditampilkan oleh pemakainya. Sehingga makna berbusana para kontestan pun berhadapan dengan tafsir publik yang beragam. Busana memiliki wajah ganda yang ambigu. Di satu sisi, wajah busana tampak menarik dan menggoda. Sebaliknya, di sisi lain, busana juga punya makna kepalsuan sekaligus mengelabui. Busana kampanye AHY -SYLVI mencontoh, atau setidak-tidaknya terinspirasi, dari seragam taktikal militer, institusi AHY berasal sebelum memutuskan terjun dalam kontestasi Pilkada DKI Jakarta 2017. Agus Harimurti Yudhoyono menyebut seragam kampanye-nya dengan istilah TactiCool. Sebuah istilah yang sangat entertaining dan gaul dengan memadukan istilah sebenarnya, taktis dan keren. Apalagi desain seragam itu dibuat body-fit alias pas badan yang membuat baju itu terlihat lebih modis. Dengan memilih warna hitam dan menempelkan aneka aksesoris membuat baju tersebut tampak sangat army-look. Untuk mengkaji

*corresponding author
\end{abstract}

Received: 29-07-2019

Acceptance: 04-08-2019

Revision: 30-07-2019

Published online: 06-08-2019

JCommSci Vol. 2 No. 2, 2019, hlm. 81 - 96 
seragam kampanye AHY - SYLVI berikut berbagai simbol yang melekat di dalamnya, maka penulis menggunakan pendekatan analisa Semiotika Roland Barthes. Perspektif Barthes tentang mitos ini menjadi salah satu ciri semiologinya yang membuka ranah baru semiologi, yaitu penggalian lebih jauh tentang penandaan untuk mencapai mitos yang bekerja dalam realita keseharian masyarakat. Dengan demikian, pendekatan teori semiotika Roland Barthes dapat digunakan untuk mengkaji pilihan busana atau seragam kampanye AHY - SYLVI sebagai sebuah simbol.

Kata Kunci: mitos militerisme; Semiotika; busana kampanye; Roland Barthes

\section{PENDAHULUAN}

Pentingnya pernanan busana kampanye dalam proses komunikasi politik di Indonesia telah mendapatkan sorotan tersendiri selama ini. Pakaian dipandang memiliki fungsi komunikasi artifaktual sebagai pernyataan politik, atau setidak-tidaknya citra yang ingin ditampilkan oleh pemakainya. Busana kampanye merupakan bentuk komunikasi nonverbal karena tidak menggunakan kata-kata lisan maupun tertulis, tapi dibentuk menjadi sesuatu yang menyerupai kalimat yang banyak memiliki kesamaan dengna cara kata-kata dirangkai dalam kalimat. Sehingga makna berbusana para kontestan pun berhadapapan dengan tafsir publik yang beragam. Seperti dijelaskan Kris Budiman busana punya wajah ganda yang ambigu. Di satu sisi, wajah busana tampak menarik dan menggoda. Sebaliknya, di sisi lain, busana juga punya makna kepalsuan sekaligus mengelabui (Budiman, 2004).

Merujuk kepada teori Fashion System dari Roland Barthes (1990), fashion adalah sebuah sistem tanda (signs). Di mana cara berpakaian tidak dilihat sebagai cara untuk menutup tubuh dengan pakaian guna menghindari udara dingin atau dari terik matahari. Cara kita berpakaian adalah sebuah tanda untuk menunjukkan siapa diri kita, nilai budaya apa yang kita anut. Maka cara berpakaian tidak lagi dipandang sebagai sesuatu yang netral dan sesuatu yang lumrah.

Dalam bukunya berjudul Fashion System, Ronald Barthes membedakan tiga tipe busana, yakni (1) image clothing, busana yang ditampilkan sebagai fotografi atau gambar; (2) written clothing, busana yang dideskripsikan secara tertulis atau ditransformasikan ke dalam bahasa; dan (3) real clothing, busana aktual yang dikenakan pada tubuh manusia, busana sebagai objek (Barthes, 1983: 3 - 5; Barthes 1981: 25 - 27).

Melalui seragam kampanye bertema army-look (real cloting) itulah AGUS HARIMURTI YUDHOYONO - SYLVIANA MURNI dalam kontestasi Pilkada DKI Jakarta 2017 yang baru saja berlangsung pada 15 Februari 2015 lalu ingin menyampaikan pesan tertentu. Meskipun AGUS HARIMURTI YUDHOYONO - SYLVIANA MURNI harus tersingkir pada putaran pertama karena perolehannya di bawah dua paslon lainnya, yaitu paslon no. 2 Ahok - Djarot dan paslon no. 3 Anis - Sandy, namun apa yang dipilih putra sulung Presiden Republik Indonesia ke-6, Susilo Bambang Yudhoyono itu menarik untuk dicermati. Hasil real count KPUD DKI Jakarta menyebutkan pasangan Ahok - Djarot mendapat 42,96\%, Anies - Sandy mendapatkan 39,97\%, dan AGUS HARIMURTI YUDHOYONO - SYLVIANA MURNI memperoleh suara sebanyak 17,06\%. 
Agus Harimurti Yudhoyono menyebut seragam kampanye-nya dengan istilah TactiCool. Memadukan istilah sebenarnya Tactical (Taktis) dan Cool (Keren). Desain seragam itu dibuat body-fit alias pas badan yang membuat baju itu terlihat lebih modis dipadu dengan memilih warna hitam dan menempelkem emblem di sana-sini. Merujuk pada buku Fashion Technology Handbook karya Meenaski Narang (2000)

Pilihan seragam kampanye model taktikal militer memang tidak bisa dipungkiri tidak bisa dilepaskan dari latar belakang militer Agus Harimurti Yudhoyono itu sendiri. Sebelum memutuskan mengundurkan diri dan maju dalam kontestasi Pilkada DKI Jakarta 2017 lalu, suami artis Anissa Pohan ini adalah seorang Danyon 203/Arya Kemuning, Tangerang, Banten berpangkat Mayor. Sebagai seorang perwira menengah AGUS HARIMURTI YUDHOYONO tentu sudah familiar dengan pakaian khas militer dalam kesehariannya.

Sebagai perwira berusia muda, Agus Harimurti Yudhoyono tentu saja paham kondisi psikologis anak muda yang selalu ingin tampil gagah. Model army-look alias busana ala tentara sudah lama menjadi minat kaum laki-laki, khusunya anak-anak muda dalam berpakaian. Kesan gagah, dan mungkin ingin ditakuti menjadi sedikit alasan orang untuk mengenakannya. Sehingga tidaklah berlebihan kalau Agus Harimurti Yudhoyono menjatuhkan pilihannya pada model army-look ini sebagai seragam kampanyenya. Selain karena terlihat lebih gagah, Agus Harimurti Yudhoyono tentu saja paham bahwa suasana politik yang ada saat ini, di mana para politisi sipil mendominasi ruang-ruang publik, maupun pos-pos kekuasaan, banyak menimbulkan kegaduhan yang berdampak pada menurunnya produktifitas kerja. Di antara suasana gaduh politisi sipil tersebut, mulai muncul kerinduan kepada kepemimpinan militer di bidang politik.

Berdasarkan penjelasan-penjelasan di atas itulah penulis tertarik memilih tema tentang sergama kampanye Agus Harimurti Yudhoyono sebagai bahan kajian penelitian ini. Sebagaimana dijelaskan Barnard (1996) bahwa kaum Marxian melihat fashion merupakan identitas kelas sosial pemakainya penulis mencurigai Agus Harimurti Yudhono telah memberikan statement kelas social dirinya melalui seragam kampanyenya. Dan untuk mengkaji seragam kampanye AGUS HARIMURTI YUDHOYONO - SYLVIANA MURNI berikut berbagai simbol yang melekat di dalamnya, penulis menggunakan pendekatan analisa Semiotika Roland Barthes.

\section{Kajian Teori}

Roland Barthes (1915-1980) adalah filsuf, kritikus sastra, dan semolog Prancis yang paling eksplisit mempraktikkan semiologi Ferdinand de Saussure, bahkan mengembangkan semiologi itu menjadi metode untuk menganalisa kebudayaan. Barthes juga dikenal sebagai seorang tokoh sentral dalam kajian bahasa, sastra, budaya, dan media, baik sebagai penemu maupun pembimbing (Allen, 2003: i). Lahir di Cherbough, Manche, Prancis pada tahun 1915, 
Barthes menghabiskan masa kecilnya diBayonne, lalu pindah ke Paris. Sewaktu muda, kesehatannya yang buruk dan kemiskinan telah menghambat karirnya (Smith, 2001: 113).

Pada tahun 1960-an, Barthes semakin dilihat sebagai tokoh terdepan dalam sebuah bentuk kritik sastra baru yang secara langsung diadu melawan macam kritik yang dipraktikkan di dalam universitas-universitas besar (Allen, 2003: 53). Allen (2003: 53) menambahkan bahwa karya-karya Barthes pada 1950-an dan 1960-an banyak menyulut debat antara bentuk-bentuk kritik yang konservatif dan avant-garde (perintis).

Barthes menerbitkan tiga buku, S/Z, Mythologies, dan The Fashion System, sebagai tiga dokumen yang menunjukkan usaha pengembangannya. Dalam $S / Z$, dia membagi-bagi novel Balzac, Sarassine, menjadi 561 lexia (satuan bacaan). Pembongkaran itu dilakukan untuk kemudian direkonstruksi kembali. Di mata Barthes, suatu teks merupakan sebentuk konstruksi belaka. Bila hendak menemukan maknanya, maka perlu dilakukan rekonstruksi dari teks itu sendiri.

Sementara, dalam The Fashion System, Barthes mengkaji fashion sebagai sebuah sistem tanda seperti model linguistik Saussure. Mythologies merupakan kumpulan esainya mengenai berbagai aspek kebudayaan Prancis, dari balap sepeda Tour de France, tarian telanjang, mainan anak-anak, wrestling, dan sebagainya. Semiotik, secara etimologis istilah semiotik berasal dari bahasa Yunani, semeion yang berarti "tanda". Secara terminologis, semiotik dapat didefinisikan sebagai ilmu yang mempelajari sederetan luas objek-objek, peristiwa-peristiwa seluruh kebudayaan sebagai tanda. (Sobur 2004:95)

\section{Fashion Sebagai Komunikasi}

Fashion merupakan istilah yang akrab dalam kehidupan sehari-hari. Kita seringkali mengidentikkan fashion dengan busana atau pakaian, padahal sebenarnya yang dikatakan fashion adalah segala sesuatu yang sedang tren dalam masyarakat. Hal ini mencakup busana, selera makan, hiburan, barangbarang konsumsi dan lain-lain. Menurut Alex Thio dalam bukunya, Sociology, "fashion is a great though brief enthusiasm among relatively large number of people for a particular innovation". Jadi sebenarnya fashion bisa mencakup apa saja yang diikuti oleh banyak orang dan menjadi tren.

Fashion sendiri dapat diartikan sebagai komunikasi non-verbal karena tidak menggunakan kata-kata lisan maupun tertulis (Davis,1992:7). Tidak sulit untuk memahami fashion sebagai komunikasi non-verbal, meskipun garmen diungkapkan dalam kata-kata seperti merk maupun slogan, disana tetap saja ada level komunikasi non verbal yang memperkuat makna harfiah slogan atau merek tersebut. Pertanyaaan pasti muncul setelah sebuah pernyataan fashion dan pakaian diartikan sebagai bentuk komunikasi non verbal . Umberto Eco menyatakan "Berbicara melalui pakaianya", yang dimaksud disini adalah menggunakan pakaian untuk melakukan apa yang dilakukan dengan kata-kata maupun lisan dalam konteks lain. (Eco, 1973:59). 
Pengirim dalam fashion ini adalah sangatlah penting, hal utamanya adalah pesan yang berada diatas segalanya, mesti disusun berdasarkan prinsip bias diperoleh kembali (retrievable) atau bisa ditemukan (discoverable). Pesan yang tak pernah diperoleh bukanlah pesan dan komunikasi tak bisa berlangsung dalam kondisi seperti itu. Efisiensi atau efektivitas proses transmisi juga penting; bila pesan tak sampai pada penerima atau sampai dalam bentuk yang berbeda atau terdistorsi, maka salah satu bagian dari proses komunikasinya, mungkin mediumnya dipandang mengandung kegagalan. Dan, efek pada penerima sangat penting dalam pandangan mahzab ini karena efek pda penerima itulah yang membentuk interaksi; interaksi social di sini dirumuskan sebagai "proses yang dengannya seorang... memengaruhi perilaku, pikiran atau respon emosional orang lain." (Fiske, 1990: 2)

Malcolm Barnard dalam bukunya Fashion Sebagai Komunikasi, memulai pengertiannya mengenai fashion dengan mengacu pada Oxford English Dictionary (OED). Menurut Malcolm: "Etimologi kata ini terkait dengan bahasa latin, Factio, yang artinya membuat". Karena itu, arti asli fashion adalah sesuatu kegiatan yang di lakukan seseorang, tidak seperti dewasa ini yang memaknai fashion sebagai sesuatu yang dikenakan seseorang. Arti sebenarnya dari fashion pun mengacu pada pengungkapan bahwa butir butir fashion dan pakaian adalah komoditas yang paling di fetish-kan (fetish adalah jimat :KBBI edisi 3), yang diproduksi dan dikonsumsi masyarakat kapitalis. Karena itu fashion dan pakaian merupakan cara yang paling signifikan yang bisa di gunakan dalam mengonstruksi, mengalami dan memahami relasi sosial dewasa ini. OED menyusun daftar Sembilan arti berbeda dari kata fashion. Salah satunya, fashion bisa saja di definisikan sebagai sesuatu bentuk dan jenis tata cara untuk bertindak. Polhemus dan Procter menunjukan bahwa "dalam masyarakat kontemporer barat, istilah fashion kerap di gunakan sebagai sinonim dari istilah dandanan, gaya dan busana" (Malcolm Barnard, Fashion sebagai komunikasi).

\section{Teori Semiotika Roland Barthes}

Busana atau pakaian tidak lagi dilihat sebagai upaya untuk menutupi tubuh menghindari dingin atau terik panas matahari. Menurut Barhtes fashion atau busana alias pakaian merupakan sebuah sistem tanda (signs). Cara kita berpakaian adalah sebuah tanda untuk menunjukkan siapa diri kita, nilai budaya apa yang kita anut. Maka cara berpakaian tidak lagi dipandang sebagai sesuatu yang netral dan sesuatu yang lumrah. Jadi pakaian yang dikenakan merupakan tanda dari diri, dan didefinisikan sebagai tanda yang memperluas makna dasar tubuh dalam konteks budaya (Danesi, 2010:255).

Mengenakan busana untuk alasan bersifat sosial merupakan ciri universal dalam budaya manusia. Cakupan yang luas dari konotasi yang dikaitkan dengan kode pakaian tidak dapat dipisahkan dari tren sosial (Danesi, 2010:266). Dan dalam tarik sejarah manapun, manusia memakai pakaian bukan hanya untuk perlindungan, tapi juga demi identifikasi dan jati diri. 
Busana sebagai fenomena kultural adalah suatu praktik pemaknaan yang berlangsung pada kehidupan sehari-hari yang turut membentuk kebudayaan sebagai suatu sistem pemaknaan.

Dalam hal ini AHY - SYLVI melalui busana kampanyenya yang mereka sebut Tacticool menampilkan sistem tanda yang mengandung identifikasi diri sekaligus mitos tertentu. Prespektif pembaca (the reader) atas tampilan busana kampanye AHY - SYLVI itulah yang akan berperan dalam memaknai tanda-tanda dalam busana kampanye tersebut.

Dalam mengamati tanda pada busana Roland Barthes membagi semiotika busana ke dalam tipe (Barthes, 1990), yaitu (1) image cloting, busana yang ditampilkan sebagai fotografi atau gambar, (2) written cloting, busana yang dideskrisikan secara tertuli, dan (3) real cloting, busana aktual yang dikenakan pada tubuh manusia. Melalui pendekatan semiotic ini kita diharapkan dapat memahami bagaimana busana sebagai image clothing maupun real clothing, yang berfungsi sebagai tanda-tanda di dalam proses produksi dan konstruksi makna. Menurut Brathes, tanda dapat berfungsi bila pembaca berperan aktif dalam mengkonstruksikan makna itu sendiri.

Signifikasi melalui pendekatan semiotika Barthes menekankan pada konsep tentang konotasi dan denotasi sebagai sebuah kunci analisisnya. Barthes mendefinisikan tanda (sign) sebagai sebuah sisten yang terdiri dari (E) sebuah ekspresi atau signifier dalam hubungannya (R) dengan content atau signified (C): ERC (Budiman:2011-39).

Dengan demikian metode Barthes tidak hanya berhenti dalam mengamati makna tanda dengan membedah penanda dan petanda. Bagi Barthes pemaknaan tersebut merupakan pemaknaan pada lapisan pertama yakni tataran denotasi. Sehingga perlu pisau analisis mendalam untuk memperhatikan pemaknaan pada lapisan kedua yakni tataran konotasi dan akhirnya tanda dalam level pertama dilakukan petanda kembali dan menimbulkan tanda kedua yakni mitos dalam masyarakat. Konotasi menurut Barthes justru mendenotasikan sesuatu hal yang ia nyatakan sebagai mitos, dan mitos ini mempunyai konotasi terhadap ideologi tertentu.

Model signifikasi ini terjadi dalam dua tahap seperti terlihat pada gambar di bawah ini:

\begin{tabular}{|c|c|}
\hline 1. SIGNIFIER (PENANDA) & 2. SIGNIFIED (PETANDA) \\
\hline 3. DENOTATIVE SIGN (TANDA DENOTATIF) \\
\hline $\begin{array}{c}\text { 4. CONNOTATIVE SIGNIFIER (PENANDA } \\
\text { KONOTATIF) }\end{array}$ & $\begin{array}{c}\text { 5. CONNOTATIVE SIGNIFIED } \\
\text { (PETANDA KONOTATIF) }\end{array}$ \\
\hline \multicolumn{2}{|c|}{ 6. CONNOTATIVE SIGN (TANDA KONOTATIF) } \\
\hline
\end{tabular}

\section{Mitos}

Bagi Roland Barthes, dalam buku Mitologi (2016) mitos merupakan sistem komunikasi karena mitos menyampaikan pesan, suatu bentuk, dan bukan suatu objek atau suatu konsep. Mitos juga merupakan bentuk tuturan (wicara), karena itu semua dapat dianggap mitos, asal ditampilkan dalam bentuk wacana. Mitos tidak ditentukan oleh materinya, melainkan oleh pesan yang disampaikan. Mitos tidak selalu bersifat verbal (kata-kata, baik lisan ataupun 
tulisan), tetapi dalam berbagai bentuk lain atau campuran antara bentuk verbal dan nonverbal, seperti dalam bentuk film, lukisan, patung, fotografi, iklan, bahkan komik.

Mitos adalah suatu tuturan (wicara) yang lebih ditentukan oleh maksud atau tujuannya daripada bentuknya. Dengan kata lain, mitos adalah "une parole volee et rendue" (suatu tuturan yang telah dicuri, kemudian dikembalikan). Hanya saja ketika dikembalikan tuturan itu tidak sama lagi, tidak seperti ketika dicuri. Pencurian sesaat inilah yang membentuk tuturan mistis tersebut.

Sesuatu bisa menjadi mitos, yang pertama, ketika hal itu telah menjadi sebuah paradigma atau sistem nilai yang berlaku mutlak dan dianggap pasti benar. Inilah yang membuat mitos menjadi bagian penting dari ideologi. Mitos adalah unsur penting yang dapat mengubah sesuatu yang kultural atau historis menjadi alamiah dan mudah dimengerti.

Yang kedua adalah adanya proses naturalisasi konsep. Sebuah makna yang diciptakan dan diletakkan kepada sebuah objek kemudian dinaturalkan sebagai sesuatu yang seolah-olah alami. Sehingga kemudian menurut Barthes manusia tidak hidup di antara benda-benda tapi opini yang diyakini kebenarannya.

Dilihat dari ciri-cirinya Barthes mengemukakan item-item yang biasannya melekat pada sebuah objek yang menjadi mitos, yaitu;

1. Inokulasi, merupakan bentuk penyangkalan atas keseluruhan keburukan atau sifat negatif dari sebuah kelompok atau subjek tertentu.

2. Privatisasi Sejarah, gejala ini merujuk pada penafikan proses sejarah. Sejarah menguap.

3. Identifikasi, gejala ini merujuk pada proses reduksi identitas.

4. Tautology, jika merujuk pada pengertian harfianya tautology adalah sebuah pernyataan majemuk yang selalu bernilai benar untuk semua kemungkinan nilai kebenaran dari pernyataan-pernyataan komponennya. Barthes menjelaskan istilah ini dengan kalimat verbal yang digunakan mendifinisikan sesuatu dengan sinonimnya.

5. Paham Neither-Norisme. Gejala ini dijelaskan Barthes sebagai figure mitologis yang muncul manakala dua hal yang berlawanan dinyatakan dengan cara seimbang dengan maksud menyangkal kedua-duanya. Atau dengan kalimat lain yang lebih sederhana adalah tidak ini, tidak itu.

6. Kuantifikasi Kualitas, gejala dimana kualitas direduksi secara kuantitatif, atau kuantitatif digunakan untuk menjelaskan kualitas. Atau Barthes menjelaskannya dengan kalimat; mitos mengubah sesuatu yang bersifat intelek menjadi sesuatu yang bersifat ekonomis; ia memahi dna menawar realitas lebih murah.

7. Statemen of Fact, gejala ini dijelaskan Barthes bahwa mitos cenderung menjadi peribahasa. Di sini mitos dianggap sebagai sebuah common sense alias sesuatu yang sudah semestinya begitu. 


\section{METODE}

Penelitian ini menggunakan paradigma kritis. Metode penelitian yang digunakan adalah penelitian kualitatif. Metode penelitian kualitatif adalah metode penelitian yang digunakan untuk meneliti pada objek yang ilmiah dimana peneliti adalah sebagai instrumen kunci, teknik pengumpulan data dilakukan secara gabungan, analis data bersifat induktif dan hasil penelitian kualitatif lebih menekankan makna dari pada generalisasi (Sugiyono,2005:1). Unit analisis dari penelitian ini adalah: Warna, Teks (Tulisan) dan Desain.

Untuk menguji keabsahan data) diperlukan teknik pemeriksaan. berdasarkan sejumlah kriteria tertentu, yaitu; derajat kepercayaaan (credibility), keteralihan (transferability), kebergantungan (dependability) dan kepastian (confirmbility). Dari empat kriteria tersebut penulis menggunakan teknik derajat kepercayaan (credibility) dalam hal ini adalah triangulasi data untuk memeriksa keabsahan data.

\section{HASIL DAN PEMBAHASAN}

Dalam kampanye Pilkada DKI Jakarta 2017, khusunya pada putaran pertama pasangan Agus Harimurti Yudhoyono dan Sylviana Murni mendapat nomor urut 1 (satu). Pasangan ini memilih busana kampanye dengan mengadaptasi seragam latihan militer atau yang disebut taktikal uniform.

Busana atau seragam taktikal lebih banyak digunakan saat latihan ataupun penugasan tentara untuk aktivitasl sipil seperti terlibat dalam bantuan kemanusiaan di tengah konflik terutama di luar negeri. Sehingga adaptasi seragam taktikal untuk kepentingan aktivitas sipil seperti kampanye Pilkada DKI Jakarta merupakan langkah yang tepat.

Merujuk pada pemahaman Barthes tersebut di atas, maka penulis melakukan pembahasan melalui skema tabel-tabel di bawah ini:

\section{Warna Hitam}

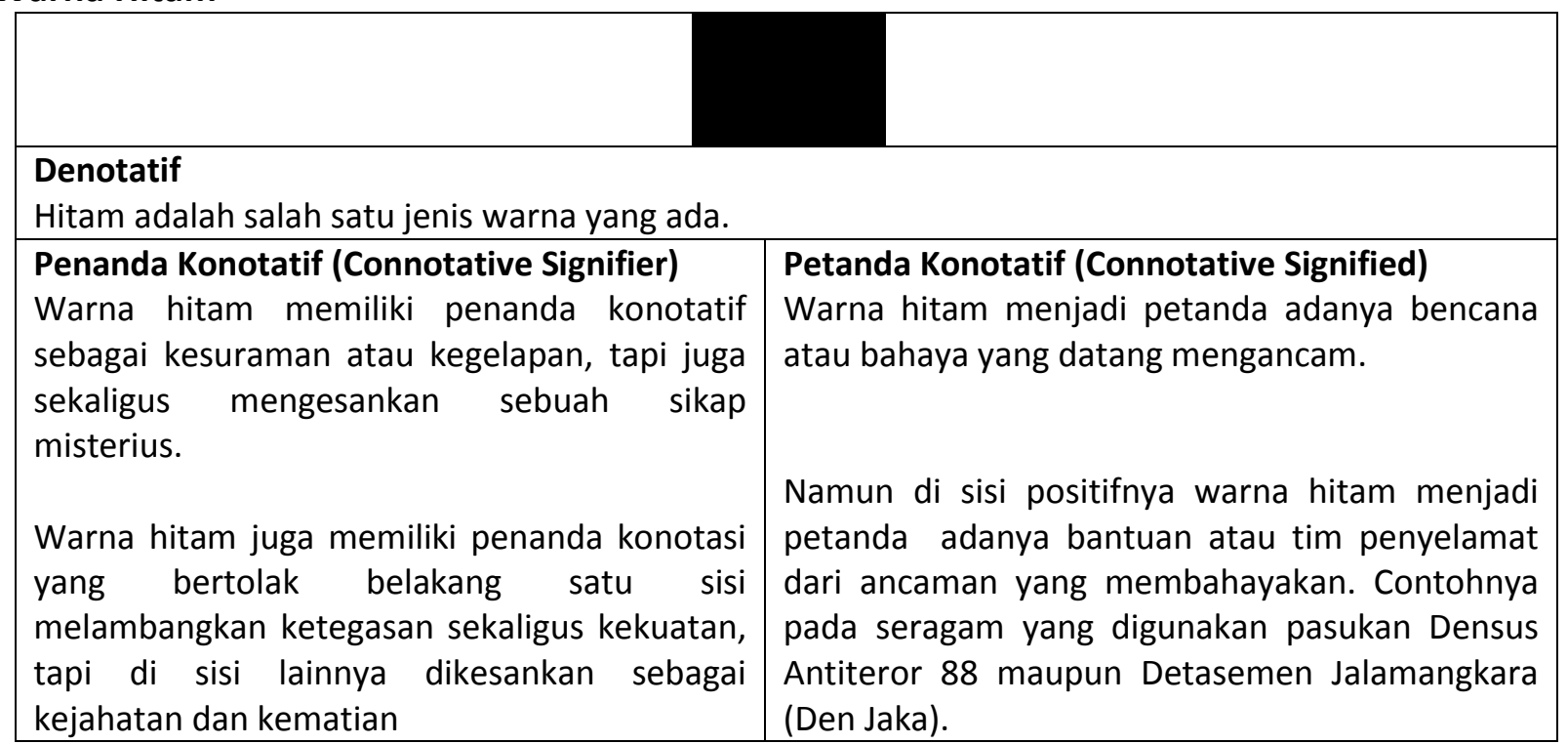


Mitos

Warna hitam menghasilkan mitos tentang keangkeran atau misterius sekaligus menghadirkan kesan gagah. Sehingga secara keseluruhan memberikan kesan elegan bagi yang mengenakan seragam berwarna hitam. Tidak mengherankan juga kalau warna hitam juga acapkali digunakan sebagai gaun pesta para pesohor dunia hiburan maupun kaum sosialitas di dunia.

\section{Dada Sebelah Kanan Lengan Panjang}

\begin{tabular}{|c|c|}
\hline \multicolumn{2}{|c|}{$\begin{array}{l}\text { Denotatif } \\
\text { Merupakan tanda pengenal atau nama dari pemilik baju, dalam hal ini adalah nama dari pasangan } \\
\text { AGUS-SYLVI. }\end{array}$} \\
\hline $\begin{array}{l}\text { Penanda Konotatif (Connotative Signifier) } \\
\text { Tulisan AGUS-SYLVI melahirkan penanda } \\
\text { konotasi sebagai sikap narsis atau keinginan } \\
\text { untuk unjuk diri di depan khalayak.Apalagi } \\
\text { tulisan itu dibuat dengan ukuran cukup besasr } \\
\text { dan warna yang kontras dengan latar } \\
\text { belakangnya, yaitu warna hitam. }\end{array}$ & $\begin{array}{l}\text { Petanda Konotatif (Connotative Signified) } \\
\text { Petanda konotasi dari tulisan ini adalah sebuah } \\
\text { rasa percaya diri dari pasangan AHY dan SYLVI } \\
\text { dalam menghadapi kontestasi Pilkada DKI Jakarta } \\
2017 \text { lalu. Rasa percaya diri atau pede ini } \\
\text { dimunculkan dengan tulisan berupa inisial dan } \\
\text { nama mereka di dada sebelah kanan busana } \\
\text { kampanyenay.. }\end{array}$ \\
\hline \multicolumn{2}{|c|}{$\begin{array}{l}\text { Mitos } \\
\text { Mitos yang ingin disampaikan adalah bahwa AGUS dan Sylvi sungguh-sungguh berjuang untuk } \\
\text { rakyat (Jakarta). }\end{array}$} \\
\hline
\end{tabular}

\section{Dada Sebelah Kiri Lengan Panjang}

\begin{tabular}{|c|c|}
\hline \multicolumn{2}{|c|}{$\begin{array}{l}\text { Denotatif } \\
\text { Angka satu merupakan tanda bahwa pasangan ini adalah nomor urut pertama dalam kontestasi } \\
\text { Pilkada DKI Jakarta } 2017 .\end{array}$} \\
\hline $\begin{array}{l}\text { Penanda Konotatif (Connotative Signifier) } \\
\text { Angka satu memberikan konotasi sebagai } \\
\text { angka kemenangan. Satu juga dapat diartikan } \\
\text { sebagai tekad yang satu atau bulat. }\end{array}$ & $\begin{array}{l}\text { Petanda Konotatif (Connotative Signified) } \\
\text { Angka satu menunjukkan mental juara, atau } \\
\text { dengan kata lain juga berarti mental pemenang. }\end{array}$ \\
\hline \multicolumn{2}{|c|}{$\begin{array}{l}\text { Mitos } \\
\text { Mitos yang ingin disampaikan adalah bahwa AHY adalah orang yang sungguh-sungguh berjuang, } \\
\text { menomor satukan kepentingan rakyat Jakarta. } \\
\text { Citra sebagai orang yang bekerja sungguh-sungguh untuk kepentingan rakya Jakarta ini menjadi } \\
\text { penting dimunculkan mengingat adanya gap yang lebar antara warga local dan kaum pendatang } \\
\text { atau etnis tertentu. }\end{array}$} \\
\hline
\end{tabular}




\begin{tabular}{|c|c|}
\hline \multicolumn{2}{|c|}{$\begin{array}{l}\text { Denotatif } \\
\text { Ketiga badge atau emblem di lengan kiri tersebut adalah tagline alias jargon yang digunakan } \\
\text { AHY-Sylvi dalam meraih simpati publik dalam gelaran Pilkada DKI Jakarta } 2017 .\end{array}$} \\
\hline $\begin{array}{l}\text { Penanda Konotatif (Connotative Signifier) } \\
\text { Ketiga badge atau emblem yang masing- } \\
\text { masing bertuliskan AHY } 4 \text { DKI 1, } \\
\text { \#JakartaUntukRakyat dan JKT } 4 \text { ALL yang } \\
\text { disusun secara vertikal melahirkan konotasi } \\
\text { kepangkatan seperti dalam seragam militer. }\end{array}$ & $\begin{array}{l}\text { Petanda Konotatif (Connotative Signified) } \\
\text { Petanda konotatifnya dari pemasangan ketiga } \\
\text { badge secara vertical layaknya tanda } \\
\text { kepangkatan militer adalah kewibawaan dan } \\
\text { kegagahan. }\end{array}$ \\
\hline \multicolumn{2}{|c|}{$\begin{array}{l}\text { Mitos } \\
\text { Mitos yang ingin disampaikan adalah bahwa AHY merupakan seorang yang tegas dan penuh } \\
\text { wibawa layaknya seorang militer. }\end{array}$} \\
\hline
\end{tabular}

\section{Lengan Sebelah Kanan}

\begin{tabular}{|l|l|}
\hline & $\begin{array}{l}\text { Petanda Konotatif (Connotative Signified) } \\
\text { Benotatif } \\
\text { Bendera negara Republik Indonesia: Merah Putih. Dan tulisan nama negara: Indonesia. }\end{array}$ \\
\hline $\begin{array}{l}\text { Penanda Konotatif (Connotative Signifier) } \\
\text { Penggunaan bendera negara dan tulisan nama } \\
\text { negara di lengan kanan memberikan konotasi } \\
\text { sebagai mewakil Indonesia. }\end{array}$ & $\begin{array}{l}\text { merah putih dan tulisan Indonesia melahirkan } \\
\text { kesan nasionalisme yang tinggi dari yang } \\
\text { memakainya. }\end{array}$ \\
\hline $\begin{array}{l}\text { Mitos } \\
\text { Mitos yang ingin disampaikan adalah bahwa AHY merupakan seorang nasionalis sejati yang } \\
\text { mencintai tanah air dan bangsanya Indonesia. Sikap nasionalisme dan patriotism acapkali } \\
\text { dihubungkan dengan aktivitas militer, sehingga mitor inilah yang dimunculkan AHY lewat bendera } \\
\text { Merah Putih dan tulisan Indonesia di lengan kanak busana kampanye. }\end{array}$ \\
\hline
\end{tabular}

\section{Dada Kanan versi Lengan Pendek}

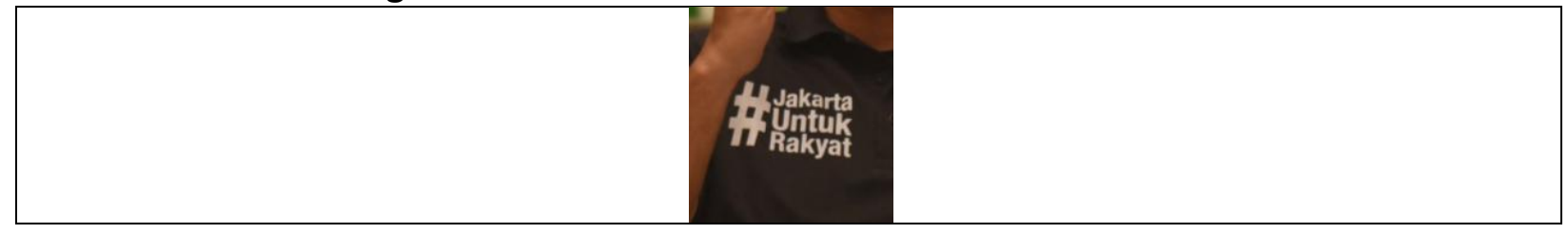




\section{Denotatif}

Tanda taggar bertuliskan Jakara Untuk Rakyat adalah salah satu tagline atau jargon yang digunakan pasangan AHY-Sylvi dalam Pilkada DKI Jakarta 2017 lalu.

\section{Penanda Konotatif (Connotative Signifier)}

Tanda tagar pada dada kanan versi baju lengan pendek memberikan pesan kampanye Jakarta Untuk Rakyat.

\section{Petanda Konotatif (Connotative Signified)}

AHY serius membenahi ibukota dan menjadikan ibukota menjadi milik dan nyaman ditinggali oleh masyarakat.

\section{Mitos}

Mitos yang ingin disampaikan adalah bahwa keikutsertaan AHY dalam kontestasi Pilkada DKI Jakart 2017 tidak lain untuk memperjuangkan rakyat alias warga DKI Jakarta agar menjadi pemilik dari ibukota yang sesungguhnya.

Ada anggapan atau isu yang muncul bahwa Jakarta telah dikuasai asing, atau kelompok etnis tertentu, yang dinilai menguasai sector ekonomi secara dominan. Dan hal ini menyingkirkan kelompok warga lokal dan melahirkan kantung-kantung kemiskinan di ibukota.

\begin{tabular}{|c|c|}
\hline \multicolumn{2}{|c|}{$\begin{array}{l}\text { Denotasi } \\
\text { Inisial AHY dengan tulisan putih inisial dari Agus Harimurti Yudhoyono. Inisial ini mengikuti pola yang } \\
\text { dilakukan ayah Agus Harimutri Yudhoyono yang populer dengan inisial SBY. }\end{array}$} \\
\hline $\begin{array}{l}\text { Penanda Konotatif (Connotative Signifier) } \\
\text { Inisial AHY di dada kiri memberikan pesan bahwa } \\
\text { yang memakai busana atau kaos tersebut adalah } \\
\text { representasi dari Agus Harimurti Yudhoyono. }\end{array}$ & $\begin{array}{l}\text { Petanda Konotatif (Connotative Signified) } \\
\text { Petanda konotatif dari inisial AHY di dada kiri } \\
\text { adalah bahwa pemakaianya merupakan } \\
\text { pendukung atau pengikut dari Agus Harimurti } \\
\text { Yudhoyono. }\end{array}$ \\
\hline \multicolumn{2}{|c|}{$\begin{array}{l}\text { Mitos } \\
\text { Mitos yang ingin disampaikan adalah bahwa pemakai kaos atau busana kampanye ini memiliki sifat } \\
\text { keperwiraan seperti AHY. Apalagi AHY dikenal sebagai sosok anak muda yang berparas rupawan } \\
\text { dengan prestasi menonjol selama berkarier di dunia kemiliteran, maupun dunia akademis yang } \\
\text { pernah ia tempuh di berbagai kampus di luar negeri. }\end{array}$} \\
\hline
\end{tabular}

Tampak Belakang

\begin{tabular}{|c|c|}
\hline Denotatif \\
Inisial AHY dan tanda tagar \#JakartaForAll
\end{tabular}




\section{Penanda Konotatif (Connotative Signifier)}

Tanda tagar pada dada kanan versi baju lengan pendek memberikan pesan kampanye Jakarta For All.

\section{Petanda Konotatif (Connotative Signified)}

Petanda konotatifnya bahwa AHY akan memperjuangkan Jakarta sebagai ibukota atau rumah bagi semua warga Jakarta tanpa melihat SARA.

\section{Mitos}

Mitos yang ingin disampaikan adalah bahwa AHY sedang memperjuangkan ibukota Jakarta dapat dinikmati oleh seluruh orang, baik warga DKI maupun pendatang bahkan warga negara asing (WNA).

Pasalnya selama ini muncul kesan bahwa Jakarta hanyalah milik orang-orang kaya, atau kelompok etinis tertentu yang dinilai menguasai secara ekonomi. Adanya isu kesenjangan atau gap antara warga local dan pendatang, atau warga miskin dengan kelompok kaya yang cukup lebar menjadi isu dalam kampanye Pilkada DKI Jakarta 2017.

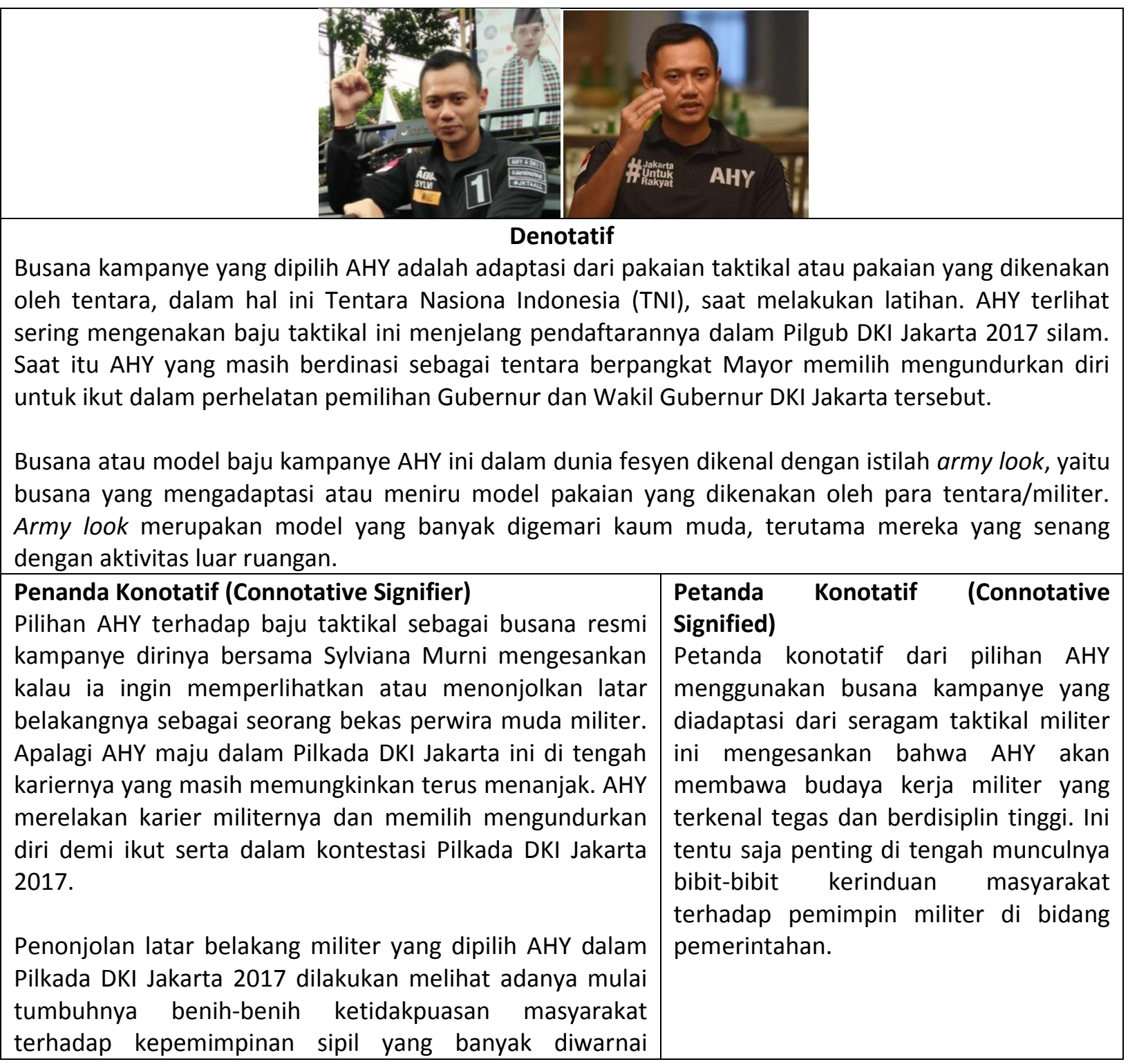


dengan isu praktik korupsi. Hal ini muncul dari hasil survey yang dilakukan oleh Lembaga Survey Segitiga Institut yang menyebutkan bahwa untuk kepemimpinan mendatang rakyat Indonesia menginginkan seorang presiden yang berasal dari kalangan militer. Seperti dikutip dalam laman $\begin{array}{llll}\text { sindonews.com } & 30 & \text { Januari } & 2916\end{array}$ (https://nasional.sindonews.com/read/1081466/12/survei -segitiga-institute-publik-rindu-pemimpin-dari-militer1454153083) Muhammad Sukron, Direktur Eksekutif Lembaga Survey Segitiga Institut ini mengatakan sekitar 40,5 persen menghendaki presiden di tahun 2019-2024 yang akan datang diambil alih kembali oleh seseorang yang berlatar belakang TNI.

Di sisi lain pilihan AHY terhaddap baju taktikal sebagai busana kampanyenya juga mengesankan AHY masih belum benar-benar ikhlas meninggalkan karier yang sudah dibangunnya sejak masih sangat muda tersebut. Hal ini terlihat dari bagaimana ekspresi AHY saat melakukan pidato perisahannya di kantor DPP Partai Demokrat dengan suara bergetar. AHY bahkan terlihat menititkan airmatanya. Hal ini seperti diberikan oleh laman www.merdeka.com pada 24 September 2016 (https://www.merdeka.com/politik/air-mata-aqus-yudhoyono-mundur-tni-demi-dki.html), "Hari ini adalah hari bersejarah dalam perjalanan hidup saya. Tepatnya jam 01.00 WIB tengah malam, saya harus tentukan pilihan dan ambil keputusan yang tidak mudah. Apakah saya jalankan karier saya di militer atau jalani di lingkungan berbeda," kata Agus, Jumat (23/9).

\section{Mitos}

Pilihan AHY menggunakan busana yang ia sebut dengan istilah Takticool ini telah melahirkan mitos bahwa militer lebih baik dari sipil. Bahwa kepemimpinan militer yang berdisiplin dan tegas akan dapat membawa bangsa Indonesia menuju ke kehidupan yang lebih baik. Apalagi beberapa tahun terakhir muncul juga meme dengan wajah Presiden RI ke-2 Soeharto dengan kalimat "Piye Kabare, Le? Masih Penak Jamanku Tokh? (Apakabarnya, nak? Masih enak jaman sayakan)" tentunya ini bagian dari adanya usaha untuk mengembalikan memori khalayak terhadap Orde Baru yang militeristik, yang dianggap berhasil mengendalikan keamanan dan stabilitas nasional. Dibandingkan dengan kepempimpinan sipil yang penuh gejolak.

Mitos militerisme yang muncul di balik busana kampanye AHY yang mengadaptasi seragam latihan atau taktikal militer ini lahir dengan penggnunaan badge yang penempatannya mengikuti pola badge dalam seragam militer., yaitu tanda pangkat di lengan kiri, dan tanda kesatuan atau negara di lengan kanan. Sedangkan nama ada di dada kanan, dan dada kiri diisi oleh wing atau tanda jasa tau penghargaan yang pernah diraih oleh pemiliknya. Kesan gagah dan berwibawa muncul dari penggunaan sejumlah badge atau emblem yang diadapatasi dengan tanda kepangkatan dan kesatuan miiliter. 
Busana sebagai fenomena kultural adalah suatu praktik pemaknaan yang berlangsung pada kehidupan sehari-hari yang turut membentuk kebudayaan sebagai suatu sistem pemaknaan. Dalam hal busana kampanye VAHY - SYLVI yang mereka sebut Tacticool menampilkan sistem tanda yang mengandung identifikasi diri sekaligus mitos tertentu. Prespektif pembaca (the reader) atas tampilan busana kampanye AHY - SYLVI itulah yang akan berperan dalam memaknai tanda-tanda dalam busana kampanye tersebut.

Dalam mengamati tanda pada busana Roland Barthes membagi semiotika busana ke dalam tipe (Barthes, 1990), yaitu (1) image cloting, busana yang ditampilkan sebagai fotografi atau gambar, (2) written cloting, busana yang dideskrisikan secara tertuli, dan (3) real cloting, busana aktual yang dikenakan pada tubuh manusia. Melalui pendekatan semiotika ini kita diharapkan dapat memahami bagaimana busana sebagai image clothing maupun real clothing, yang berfungsi sebagai tanda-tanda di dalam proses produksi dan konstruksi makna. Menurut Brathes, tanda dapat berfungsi bila pembaca berperan aktif dalam mengkonstruksikan makna itu sendiri. Signifikasi melalui pendekatan semiotika Barthes menekankan pada konsep tentang konotasi dan denotasi sebagai sebuah kunci analisisnya. Barthes mendefinisikan tanda (sign) sebagai sebuah sisten yang terdiri dari (E) sebuah ekspresi atau signifier dalam hubungannya (R) dengan content atau signified (C): E-R- C (Budiman:2011-39).

Dengan pemahaman tersebut, mitos merupakan sistem representasi-produksi makna-dalam penandaan yang berfungsi untuk mendistorsi dan kemudian menaturalisasi sebuah pengetahuan atau ideologi sehingga menjadikannya sebagai sesuatu yang wajar dalam sebuah masyarakat atau bangsa; praktik depolitisasi. Apa yang harus dipahami adalah bahwa mitos-mitos dalam masyarakat tidak pernah bersifat netral (nir-kepentingan) karena selalu melibatkan motivasi-motivasi partikular sehingga untuk bisa mengkajinya secara komprehensif dibutuhkan kemampuan untuk menghubungkan kode-kode mitis dengan kode-kode kultural yang ada dalam masyarakat (Sunardi, 2004: 88-101) ataupun formasi sosial, ekonomi, dan politik yang berlangsung.

Merujuk pada busana kampanye yang digunakan AHY-Syvli dalam kontestasi pilkada DKI Jakarta tahun lalu terlihat upaya proses naturalisasi konsep tentang ketegasan, wibawa dan displin dalam taktikal militer yang dimodifasi menjadi tacticool. Proses modifikasi ini mengacu pada desain atau dalam dunia fashion disebut army-look. Model busana army look menjadi salah satu model busana yang selalu digemari anak-anak muda sepanjang waktu.

AHY yang memiliki latar belakang militer dengan pangkat terakhir Mayor, membaca suasana politik nasional yang mulai memunculkan suara-suara menampilkan pemimpin berlatarbelakang militer. Panggung politik berisi para politisi sipil mendominasi ruang-ruang publik, maupun pos-pos kekuasaan, dianggap banyak menimbulkan kegaduhan yang berdampak pada menurunnya produktifitas kerja. Seperti yang terjadi selama kurun 32 tahun di bawah rezim militer-otoriter Soeharto. Keinginan masyarakat terhadap tampilnya pemimpin berlatar belakang militer ini terlihat dari survey yang dilakukan oleh Segitiga Institute yang 
dipublikasikan pada 30 Januari 2016 silam. Melalui Direktur Eksekutifnya, Muhammad Sukron menyampaikan hasil survey sebagai berikut bahwa $40.5 \%$ masyarakat menginginkan pemimpin nasional berlatar belakang militer.

Hasil survey yang dilakukan awal tahun 2016 silam itu merepresentasikan kuatnya mitos tentang superioritas militer. Proses reformasi yang semual digadang-gadang akan membawa bangsa dan negara Indonesia menuju level yang lebih baik, sampai hari ini belum juga berwujud nyata. Malah praktik korupsi kian banyak terjadi sampai ke daerah. Stabilitias harga yang rentan terhadap inflasi juga menjadi catatan buruk memori masyarakat. Sementara generasi yang hidup dalam alam Orde Baru yang militeristik merasakan stabilitas ekonomi dan kemanan yang cukup terjaga, kendati suasana politik begitu mencekam dan otoriterianistik. Isu komunisme dan bangkitnya PKI menjadi sarana yang empuk untuk membangkitkan memori kolektif masyarakat terhadap patriotisme militer, atau lebih khususnya TNI Angkata Darat. Mereka yang dimitoskan sebagai pahlawan super yang menjaga negara dari ancaman komunisme di tahun 1965.

Mitos superioritas militer terhadap sipil inilah yang membuat sejumlah organisasiorganisasi kemasyarakatan-pemuda memilih seragamnya dengan gaya militer lengkap dengan baret dan emblem serta sepatu larsnya. Padahal ormas berseragam Tentara Nasional Indonesia (TNI) jelas dilarang dalam Undang-undang. Hal itu sesuai Pasal 59 Undang-undang Nomor 17 Tahun 2013 tentang Penggunaan Atribut Militer.

Menghindari larangan aturan tersebut model busana army-look kemudian menjadi pilihan. Model inilah yang menjadi pilihan AHY-Sylvi sebagai busana kampanyenya. Pada busana kampanye yang disebut tacticool ini kemudian dihilangkan tanda kepangkatan, kesatuan atau matra angkatan, dan digantikannya dengan kalimat yang menjadi tagline kampanye mereka, yaitu; AHY 4 DKI 1, \#JakartaUntukRakyat dan \#JKT4ALL. Tentu saja hal itu bukan semata-mata bahawa AHY berlatar belakang militer seperti yang disampaikannya dalam wawancara dengan detik.com berikut ini: "Ini (model baju) tactical, biasa digunakan military. Karena sampai kapanpun beginilah saya," ungkap Agus saat bertandang ke redaksi detikcom, Jakarta Selatan, pada Kamis (6/10).

\section{SIMPULAN}

Makna dari tanda bersifat arbiter (mana suka), maka setiap tanda memiliki makna yang berbeda di setiap bingkai pengalaman dan budaya seseorang. Hal ini sekaligus menekankan salah satu area penting yang disentuh Barthes dalam studi tentang tanda adalah peran pembaca (the reader). Walaupun konotasi merupakan sifat asli tanda, namun hal ini membutuhkan keaktifan pembaca agar dapat berfungsi. Berdasarkan hasil penelitian dan analisis yang dilakukan penulis bisa disimpulkan bahwa AHY-Syvli memilih dan menggunakan busana kampanye dengan nama Tackticool bergaya army look bertujuan menampilkan kesan atau mitos ketegasan, wibawa dan gagah. Hal ini seringkali terlihat dari profile seorang tentara 
atau militer. Kesan gagah seperti anggota militer ini tentu saja banyak diminati oleh kaum muda atau remaja. Dengan demikian bisa disimpulkan juga bahwa AHY menyasar pemilih pemula dan anak muda pada umumnya. Tampak juga adanya kecenderungan kerinduan masyarakat terhadap stabilitas politik dan keamanan yang mana hal ini tidak terlihat selama kepemimpinan nasional dipegang oleh sipil. Adanya kerinduan terhaap kepemimpinan militer inilah yang coba ditangkap AHY melalui penggunakan simbol-simbol yang mengadapatasi simbol-simbol di dunia kemiliteran. Selain itu, Secara pribadi AHY masih belum benar-benar merelakan karier militernya diakhiri dengan keputusannya mengundurkan diri untuk maju dalam kontestasi Pilkada DKI Jakarta, sehingga AHY memilih busana kampanye yang mengadaptasi busana militer dalam hal ini seragam taktikal.

\section{DAFTAR PUSTAKA}

Arifin, A. (2011). Komunikasi Politik. Yogyakarta: Graha IImu. (2014). Politik Pencitraan - Pencitraan Politik. Graha IImu.

Yogyakarta

Barnard, M.(2012). Fashion Sebagai Komunikasi. Yogyakarta: Jalasutra, Barthes, R. (2007) Petualangan Semiologi. Yogyakarta: Pustaka Pelajar. (2012) Elemen-Elemen Semiologi. Yogyakarta: Jalasutra (2015) Mitologi, Yogyakarta: Kreasi Wacana

Bourdieou, P. (2007). Menyingkap Kuasa Simbol. Yogyakarta: Jalasutra

Budiman, K. (2011). Komunikasi Visual: Konsep, Isu dan Problem Ikonsitas, Bandung: Jalasutara.

Budiawan DR.(2014) Nation dan Nasionalisme, Ombak, Jakarta

Bungin, B. (Ed.) (2015). Metodologi Penelitian Kualitatif: Aktualisasi Metodologis ke Arah Varian Kontemporer. Jakarta: Rajawali Grafindo Persada.

Fiske, John (2016), Pengantar Ilmu Komunikasi. Jakarta: Rajawali Pers,

Littlejoh, Stephen W, Karen A. Foss, Jamdan, M.Y. (trans). Teori Komunikasi. Jakarta: Penerbit Salemba Humanika.

Khaelan, MS. (2009) Filsafat Bahasa Semiotika dan Hermeneutika. Yogyakarta: Paradigma, Moleong, L.J (2014). Metodologi Penelitian Kualitataif Edisi Revisi. Bandung: Remaja Rosdakarya.

Mulyana, D. (2014) Komunikasi Politik dan Politik Komunikasi. Bandung: Rosda, Piliang, Y.A, (2012) Semiotika dan Hipersemiotika, Bandung: Matahari

Sobur, A. (2013) Semiotika Komunikasi . Bandung: Rosda. 